\title{
The debt and fiscal risks of local and regional self-government units in Croatia
}

\author{
ANTO BAJO Institute of Public Finance \\ MARKO PRIMORAC Faculty of Economics and Business Zagreb
}

The fiscal position of local and regional self-government units (especially of the City of Zagreb) is significantly influenced by the operations of their utility firms. The debt of the utility firms is often higher than the debt accumulated by the local government units. For this reason the liabilities of utility firms have become a threat to the financial stability of local and regional self-government units, especially of the City of Zagreb.

\section{INTRODUCTION}

Assessments and analyses of the debt and indebtedness of local and regional self-government units (hereinafter: local government units) in the Republic of Croatia, have mainly been focused on direct liabilities. This approach ignored a significant portion of the potential explicit but also implicit liabilities (Bajo and Primorac, 20Io). Local units and their firms operate on the principle of communicating vessels, among which there are constant financial spillovers. Although local units' debt can hardly pose a threat to the sustainability of government finances, uncontrolled growth of the liabilities of utility firms may affect the liquidity and the fiscal sustainability of the local sector. The lack of insight into the extent of the liabilities of local government units' firms - particularly utilities - creates the impression that the exposure of the central government to the debt of local government units is relatively low or negligible.

The analysis of the debt covered 557 local government units and I89 utility firms engaged in water supply and drainage, sanitation and spatial development, cemeteries, retail markets and transport. Unfortunately, not all the firms could be classified by the local government units they belong to because several local government units turned out to be (majority or minority) owners of the same firms.

\section{INTERDEPENDENCE OF LOGAL GOVERNMENT UNITS AND THEIR UTILITY FIRMS}

The financial operations of local government units and their utility firms are highly interwoven. Due to the rather restrictive borrowing limits, local government units often borrow through their utility firms (mainly for capital projects financing), thus sidestepping the budgetary constraints. 
Local government units have shares and equity in commercial and utility firms. In 2013 they owned HRK I5.6bn (almost $20 \%$ of total assets) of shares and equity, of which HRK I3.3bn related to shares and equity of firms in the public sector (Table I).

Table I.

Shares and equity of local government units in 2013 (in billion HRK)

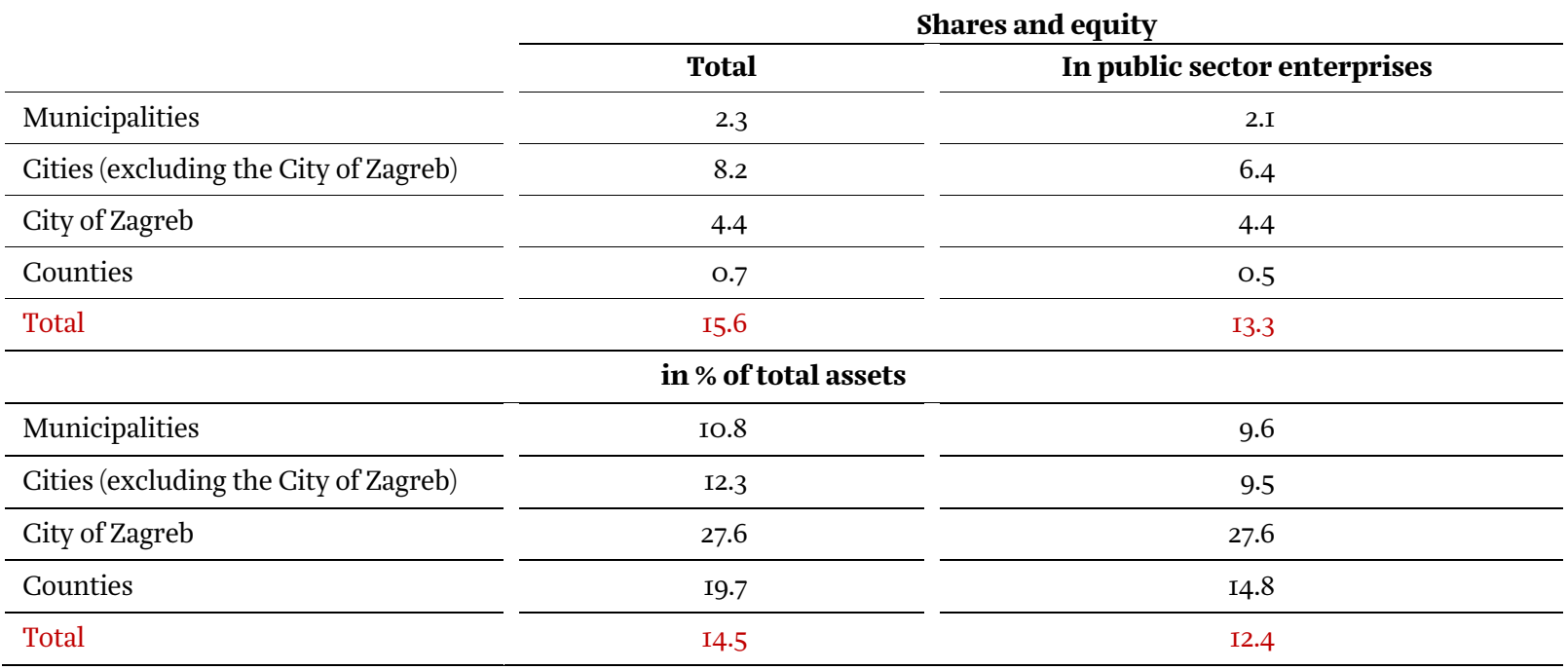

Source: The financial statements of local government units for 2013

The City of Zagreb alone had almost $28 \%$ of its total assets (HRK $4.4 \mathrm{bn}$ ) in shares and equity of firms in the public sector. Accordingly, the transactions, i.e. spillovers of financial resources from the local government units to their utility firms are intense. Subsidies and capital grants from local government units to firms in the public sector in 2013 amounted to around HRK I.9bn (Table 2).

Table 2.

Subsidies and capital grants of local government units in 2013 (in million HRK)

\begin{tabular}{|c|c|c|c|}
\hline & $\begin{array}{l}\text { Subsidies to public } \\
\text { sector enterprises }\end{array}$ & $\begin{array}{l}\text { Capital grants to credit and } \\
\text { other financial institutions } \\
\text { and public sector enterprises }\end{array}$ & Total \\
\hline Municipalities & 36 & 72 & 108 \\
\hline Cities (excluding the City of Zagreb) & 203 & $3 \mathrm{I} 6$ & 519 \\
\hline City of Zagreb & 849 & 377 & $\mathrm{I}, 227$ \\
\hline Counties & 20 & 33 & 53 \\
\hline Total & $\mathrm{I}, \mathrm{IO} 7$ & 799 & I,906 \\
\hline \multicolumn{4}{|c|}{ in \% of total expenditures } \\
\hline Municipalities & I.4 & 2.8 & 4.2 \\
\hline Cities (excluding the City of Zagreb) & 2.9 & 4.5 & 7.3 \\
\hline City of Zagreb & 14.3 & 6.4 & 20.7 \\
\hline Counties & 0.6 & I.I & I.7 \\
\hline Total & 5.9 & 4.3 & I0.2 \\
\hline
\end{tabular}

Source: The financial statements of local government units for 2013

The City of Zagreb has - for such transfers - allocated a sum of over HRK I.2bn, which accounts for over $20 \%$ of its total expenditures. Subsidies from the City of Zagreb to the Zagreb Electric Tram (ZET) in 2OI3 amounted to more than HRK $772 \mathrm{~m}$ (in the same year, consolidated operating revenue of the Zagreb Holding amounted to HRK 6.Ibn, which means that subsidies to ZET represented about I2.6\% of total 
operating revenue of the entire Zagreb Holding). These examples should be more than enough for the Government and the Ministry of Finance to prescribe the obligation of preparing the consolidated financial statements of local government units and their (utility) firms.

\section{LOGAL GOVERNMENT UNITS' DIREGT AND CONTINGENT LIABILITIES}

The budgets of local government units have, in the last four years, amounted to around HRK 22bn on average. In 2010 and 2011 budgets were in deficit of about HRK I5Om. In 2012 budgets achieved a surplus of HRK IOom and in 2013 as much as HRK 80om (Table 3).

Table 3.

Surplus/deficit of local government units' budgets from 2010 until 2013 (in billion HRK)

\begin{tabular}{|c|c|c|c|c|c|}
\hline & & 2010 & 2011 & 2012 & 2013 \\
\hline \multirow{3}{*}{ Total } & Revenue & 2I.9 & 2I.O & $2 \mathrm{I} \cdot 3$ & 22.9 \\
\hline & Expenditure & 22.0 & $2 \mathrm{I} .2$ & $2 \mathrm{I} \cdot 3$ & 22.2 \\
\hline & Surplus/deficit & $-0 . \mathbf{I}$ & -0.2 & O.I & 0.8 \\
\hline \multirow{3}{*}{ Counties } & Revenue & 3.4 & 3.4 & 3.4 & 3.7 \\
\hline & Expenditure & 3.4 & 3.4 & 3.4 & 3.7 \\
\hline & Surplus/deficit & 0.0 & 0.0 & O.I & 0.0 \\
\hline \multirow{3}{*}{ City of Zagreb } & Revenue & 6.3 & 6.2 & 6.3 & 7.3 \\
\hline & Expenditure & 6.2 & 6.3 & 6.3 & 6.6 \\
\hline & Surplus/deficit & O.I & -0.1 & 0.0 & 0.7 \\
\hline \multirow{3}{*}{ Cities } & Revenue & 8.6 & $8 . I$ & 8.4 & 8.6 \\
\hline & Expenditure & 8.8 & 8.2 & 8.3 & 8.4 \\
\hline & Surplus/deficit & -0.2 & -0.1 & O.I & O.I \\
\hline \multirow{3}{*}{ Municipalities } & Revenue & 3.5 & 3.3 & 3.3 & 3.4 \\
\hline & Expenditure & 3.5 & 3.4 & 3.3 & 3.4 \\
\hline & Surplus/deficit & 0.0 & 0.0 & 0.0 & 0.0 \\
\hline
\end{tabular}

Source: The financial statements of local government units for 2013

The largest individual surplus of HRK o.7bn was achieved in 2013 by the City of Zagreb thanks to higher receipts from income tax, which is mainly related to the return of the excess revenue for decentralized functions - about HRK 0.5bn. It can be concluded that the financial performance of local government units by 2013 is stable. It is characterized by high operating surpluses, whereby occasional shortages are mainly a result of a higher expenditure for the acquisition of nonfinancial assets.

Table 4.

Local government borrowing limits from 2008 until 2013 (in million HRK)

\begin{tabular}{|c|c|c|c|c|c|c|}
\hline & 2008 & 2009 & 2010 & 2011 & 2012 & 2013 \\
\hline Borrowing limit (\% of operating revenue) & 2.3 & 2.3 & 2.3 & 2.3 & 2.5 & 2.5 \\
\hline Maximum amount of borrowing & 499 & 542 & 516 & 486 & 506 & 517 \\
\hline Realized amount of direct borrowing & 564 & 496 & 604 & 687 & 544 & 606 \\
\hline Difference (excess borrowing) & 65 & -46 & 88 & $2 \mathrm{OI}$ & 38 & 89 \\
\hline
\end{tabular}

Note: The annual amount of the direct borrowing represents the total sum of the value of receipts from the sale of securities and receipts from borrowing of all local government units in particular year.

Source: Authors' calculations based on the financial statements of local government units from 2008 until 2013

${ }^{\mathrm{r}}$ Consolidated financial statements as of December 3I, $2 \mathrm{OI3}$ together with the independent auditor's report. 
By 2012 the Government had given approval for local government borrowing up to $2.3 \%$ of total operating revenue of all local government units together (from 2012 2.5\%). From 2008 to 2013, local government units almost continuously borrowed over the limit (Table 4). But that does not necessarily mean that the debt was illegal.

The Acts on the Execution of the State Budget lay down the conditions under which certain borrowings are not subject to limitations. In 2013, the debt limit did not apply to local government borrowing for which the Government had given its consent by December 3I, 2012 but were not used in 2012, local government units in the areas of the special state concern (ASSC), local government units that have borrowed for projects co-financed from the EU funds, as well as for projects aimed to improve energy efficiency with the participation of local government units. In 20II, local government units' borrowing reached a record of HRK $687 \mathrm{~m}$, which was HRK 2OIm above the ceiling. The quite restrictive borrowing limits have led local units to borrow through their utility firms in order to finance capital projects.

Direct local government debt includes contractual obligations to repay principal and interest of the debt created by loans and bonds. Direct local government debt increased from HRK 2.7bn in 2008 to HRK 3.Ibn in 2013 (Table 5).

Table 5.

The amount and the structure of local government debt from 2008 until 2013 (in million HRK)

\begin{tabular}{|c|c|c|c|c|c|}
\hline & Cities & Gity of Zagreb & Municipalities & Counties & Total \\
\hline 2008 & $\mathrm{I}, 709$ & 467 & 259 & 229 & 2,664 \\
\hline 2009 & $\mathrm{I}, 8 \mathrm{O} 2$ & 509 & 287 & 295 & 2,893 \\
\hline 2010 & I,959 & $54 \mathrm{I}$ & 280 & $3 \mathrm{I} 8$ & 3,098 \\
\hline $2 \mathrm{OII}$ & I,995 & $5 \mathrm{I} 2$ & 272 & $35 \mathrm{I}$ & 3,I3I \\
\hline 2012 & $\mathrm{I}, 882$ & 520 & 296 & 390 & 3,087 \\
\hline 2013 & $\mathrm{I}, 88 \mathrm{O}$ & 520 & 373 & 339 & 3,II2 \\
\hline
\end{tabular}

Source: The financial statements of local government units for $2 \mathrm{OI} 3$

The total debt structure is dominated by loans with a share of more than 9o\% (Table 8). Loans of cities represent over $51 \%$ of the total debt of local government units. In 20I3, the financial liabilities of cities reached HRK I.8bn, out of which HRK 520m were the financial liabilities of the City of Zagreb alone. In the same year the debt of municipalities amounted to HRK 373m and the debt of counties HRK 339m.

Guarantees for utility firms' borrowing represent the potential liability of local governments that guarantee the repayment of the loan with their own revenue if their institutions and firms (the original debtors) fail to do so. Guarantees issued to firms and institutions should be included in the total coverage of local government debt. However, the risks of financial operations of local utility firms are much larger, because guarantees are made only for a portion of the credit borrowing. The share of local utility firms' liabilities covered by guarantees reduced from $48 \%$ in 2011 to $39 \%$ in 2013 (Table 6).

Table 6.

Total financial liabilities of utility firms from $201 \mathrm{I}$ until 2013 (in billion HRK)

\begin{tabular}{|c|c|c|c|}
\hline & $20 I I$ & 2012 & 2013 \\
\hline Long-term financial liabilities & 5.5 & 5.3 & 5.7 \\
\hline Short-term financial liabilities & I.5 & I. 6 & I.6 \\
\hline Total & 7.0 & 6.9 & 7.2 \\
\hline Out of which Zagreb Holding (total long- and short-term) & 5.5 & 5.4 & 5.8 \\
\hline Guarantees/long-term financial liabilities & 0.5 & 0.4 & 0.4 \\
\hline
\end{tabular}

Source: The financial statements of local government units' utility firms from $201 \mathrm{O}$ until 2013 
By 20Io, borrowing guarantees had expanded to HRK 3bn and then gradually declined to HRK 2.2bn in 2013 (Table 7).

Table 7.

The amount and the structure of local government units' active guarantees from 2008 until 2013 (in million HRK)

\begin{tabular}{|c|c|c|c|c|c|}
\hline & Gities & Gity of Zagreb & Municipalities & Counties & Total \\
\hline 2008 & $\mathrm{I}, \mathrm{O} 74$ & $\mathrm{I}, 363$ & III & 395 & 2,943 \\
\hline 2009 & 809 & $\mathrm{I}, 52 \mathrm{O}$ & 179 & 457 & 2,965 \\
\hline 2010 & $\mathrm{I}, \mathrm{I} 59$ & $\mathrm{I}, 238$ & I68 & 448 & 3,OI3 \\
\hline $2 \mathrm{OII}$ & $92 \mathrm{I}$ & 1,082 & I9I & 427 & $2,62 I$ \\
\hline 2012 & 783 & 973 & $\mathrm{I} 74$ & 362 & 2,29I \\
\hline 2013 & 784 & 782 & 157 & 476 & 2,199 \\
\hline
\end{tabular}

Source: The financial statements of local government units for 2013

The largest individual amount of active guarantees relates to the City of Zagreb and equals the amount of active guarantees of all other cities together. Since 2005, local government units have kept auxiliary records about guarantees issued and plan the amount of the guarantee reserves used to cover the potential liabilities arising from the calling of guarantees.

\section{LOCAL GOVERNMENT UNITS' NET-DEBT}

The net-debt is the difference between the financial assets and financial liabilities. It is a useful indicator of solvency and ability to repay the principal and interest of the debt. Financial assets of local government units consist of cash, deposits, loans, securities, shares and equity and claims for revenue. Financial liabilities include all obligations of local government units related to checks and bills, other securities and loans.

In assessing the financial assets it should be noted that shares and equity are not expressed at the market value, because the shares of firms owned by local government units are not actively traded on the stock exchange. In contrast, financial liabilities are expressed at the market value because the market value of loans and other contractual obligations is easily determined. Therefore, it is necessary to separately observe the net financial position with the values of shares and equity and without them.

The value of the financial assets greatly exceeds the value of the financial liabilities of local government units (Table 8). The main reason for this is the high level of financial assets in the form of shares and equity in firms and institutions. Without the value of shares and equity, claims for operating revenue and claims from the sale of non-financial assets, the net financial position is negative - financial liabilities are greater than financial assets (in 2013 by about HRK $385 \mathrm{~m}$ ).

A closer look at the financial position of local government units reveals that cities have higher potential problems with liquidity because their financial liabilities significantly exceed their financial assets (for almost HRK I.2bn). In the City of Zagreb alone the amount of the financial liabilities exceeds the amount of the liquid financial assets for around HRK 222m. Counties (which have a significant value of liquid financial assets) and municipalities have much more favourable financial positions (Table 8).

Although it could be concluded at first sight that local government units are not over-indebted and their financial operations are safe and adequate, the largest source of fiscal risk for the local government units stems from the operations of their utility firms. Therefore, in order to get a more detailed insight into 
the real exposure of local government units to contingent as well as direct liabilities, it is necessary to take a look at the financial performance and liabilities of their utility firms.

Table 8.

Net-financial assets of local government units in 2013 (in million HRK)

\begin{tabular}{|c|c|c|c|c|c|c|}
\hline & & Cities & $\begin{array}{l}\text { City of } \\
\text { Zagreb }\end{array}$ & $\begin{array}{c}\text { Munici- } \\
\text { palities }\end{array}$ & Counties & Total \\
\hline I & Financial assets & $\mathrm{I} 2,524$ & 6,368 & 4,352 & I,808 & $25,05 I$ \\
\hline II & Cash in bank and treasury & 475 & $2 \mathrm{IO}$ & 439 & 323 & $\mathrm{I}, 447$ \\
\hline $\mathrm{I} 2$ & Deposits and others & 298 & 44 & I45 & I88 & 675 \\
\hline I3 & Loans (given) & 149 & 26 & 52 & 353 & 579 \\
\hline I4 & Securities & 5 & I8 & 2 & $\mathrm{O}$ & 26 \\
\hline 15 & Shares and equity & 8,232 & 4,373 & 2,344 & $66 I$ & I5,6II \\
\hline I6 & Claims for operating revenue & 2,574 & 1,247 & $\mathrm{I}, \mathrm{O} 46$ & 275 & $5, \mathrm{I} 43$ \\
\hline 17 & Claims from the sale of nonfinancial assets & $79 \mathrm{I}$ & 449 & 324 & 7 & $\mathrm{I}, 57 \mathrm{I}$ \\
\hline I9 & $\begin{array}{l}\text { Expenditures of future periods and accrued } \\
\text { revenue }\end{array}$ & 167 & 26 & 34 & I8 & 245 \\
\hline Ia & Financial assets (I-I5-I6-I7) & 927 & 298 & 637 & 864 & 2,727 \\
\hline 2 & Financial liabilities & $\mathrm{I}, 88 \mathrm{O}$ & 520 & 373 & 339 & 3,II2 \\
\hline 25 & Liabilities for bonds & 283 & $\mathrm{O}$ & 4 & $\mathrm{O}$ & 287 \\
\hline \multirow[t]{3}{*}{26} & Liabilities for loans & $\mathrm{I}, 597$ & 520 & 369 & 339 & 2,825 \\
\hline & Net-financial assets (I-2) & Io,644 & 5,847 & 3,979 & $\mathbf{I , 4 6 9}$ & 21,939 \\
\hline & Net-financial assets (ra-2) & -953 & -222 & 264 & 525 & -385 \\
\hline
\end{tabular}

Source: The financial statements of local government units for 2013

\section{THE DEBT OF LOGAL GOVERNMENT UNITS AND UTILITY FIRMS}

The amount of utility firms' debt is analysed based on the data available for I89 firms engaged in water supply and drainage, sanitation and spatial development, cemeteries, retail markets and transport.

To reveal the real image of the size of the utility sector it should be noted that utility firms generate more than HRK 9bn revenue and expenditure, with Zagreb Holding alone generating almost half of the total amount. In 2012 the utility firms generated an aggregate loss of HRK 323m (at the level of the entire sector). The situation improved in 2013 when the financial result was positive, but the surplus was only HRK $7 \mathrm{~m}$ (Table 9).

Table 9.

Profit/loss of utility firms from 2012 until 2013 (in million HRK)

\begin{tabular}{|c|c|c|c|c|c|c|}
\hline & \multicolumn{2}{|c|}{ Total } & \multicolumn{2}{|c|}{ Zagreb Holding } & \multicolumn{2}{|c|}{ Other utilities } \\
\hline & 2012 & 2013 & 2012 & 2013 & 2012 & 2013 \\
\hline Total revenue & 8,747 & 9,424 & 3,842 & 4,617 & 4,905 & 4,807 \\
\hline Total expenditure & 9,069 & 9,417 & 4,207 & 4,586 & 4,863 & $4,83 \mathrm{I}$ \\
\hline Profit/loss & -323 & 7 & -365 & $3 \mathrm{I}$ & 42 & -24 \\
\hline $\begin{array}{l}\text { Financial } \\
\text { expenditure }\end{array}$ & 482 & 863 & 408 & 784 & 74 & 79 \\
\hline
\end{tabular}

Source: The financial statements of local government units for 2012 and 2013

The debt of local government units' firms. Total financial liabilities of utility firms (loans and securities) in 2013 amounted to HRK 7.2bn, which is double the amount of local government units' direct liabilities (Table Io). Total local government units' revenue in 2013 amounted to about HRK 23bn with HRK 3 bn of

6 NEWSLETTER 93 | A. BAJO \& M. PRIMORAC | The debt and fiscal risks of local and regional... I Institute of Public Finance 
direct liabilities. On the other hand the utility firms generated about HRK 9.5bn in revenue, but they have accumulated more than HRK $7 \mathrm{bn}$ of direct liabilities. Although the debt financing of the profitable non-financial assets might be generally desirable, it should be noted that illiquid utility firms rarely end up in bankruptcy. Financial difficulties of utility firms are usually solved in two ways: by increasing the price of utilities or (more often) with transfers from the local government budget (bailout). Due to the fact that errors in the financial management of utility firms are usually covered from the local government budgets, the borrowing of utility firms should be treated equally as restrictively as that of local government units.

Table Io.

Total direct and contingent debt of local government units from 2011 until 2013 (in million HRK)

\begin{tabular}{|c|c|c|c|c|c|c|c|}
\hline & Cities & $\begin{array}{c}\text { Gity } \\
\text { of Zagreb }\end{array}$ & Municipalities & Counties & $\begin{array}{c}\text { Zagreb } \\
\text { Holding }\end{array}$ & $\begin{array}{c}\text { Other } \\
\text { utilities }\end{array}$ & Total \\
\hline $2 \mathrm{OII}$ & I,995 & 512 & 272 & $35 \mathrm{I}$ & 5,492 & $\mathrm{I}, 523$ & IO,I45 \\
\hline 2012 & $\mathrm{I}, 882$ & 520 & 296 & 390 & 5,355 & I,5I9 & 9,962 \\
\hline 2013 & $\mathrm{I}, 88 \mathrm{O}$ & 520 & 373 & 339 & 5,766 & $\mathrm{I}, 462$ & IO,340 \\
\hline
\end{tabular}

Source: The financial statements of local government units and their utility firms from $201 \mathrm{I}$ until 2013

Better insight into the actual state of the debt can be obtained by separately observing the financial liabilities of Zagreb Holding and other utility firms. In 2013, the Zagreb Holding had about HRK 5.8bn of direct liabilities (about $80 \%$ of total cumulative liabilities of all utility firms in the Republic of Croatia). The financial liabilities of all other utility firms amounted to only about HRK I.5bn. Similarly, the financial expenditure of local government units seems to be very high exclusively because of the City of Zagreb and Zagreb Holding whose financial expenditure in 2013 - compared to the previous year almost doubled (Table 9). The financial expenditure of the Zagreb Holding in 2013 amounted to HRK $784 \mathrm{~m}$, whereas the financial expenditure of all other utility firms together amounted to HRK 79m.

The total debt of local government units. Total financial liabilities of local government units (direct and contingent) amount to over HRK IO.3bn. If this is borne in mind, the entire local sector could be characterized as fairly indebted. However, a more detailed insight into the debt structure reveals a very different picture. The structure of local government debt is dominated exclusively by the liabilities of the City of Zagreb, which - together with Zagreb Holding - accumulated a debt of about HRK 6.3bn up to 2013. The total aggregate debt of all other local government units and their utility firms together amounted to about HRK 4bn. Accordingly, all local government units except for the City of Zagreb and the Zagreb Holding can be commended. Direct liabilities of local government units are generally low and borrowing through utility firms is not excessive. The exception is the City of Zagreb where most of the credit activities are performed through Zagreb Holding. At the same time, Zagreb Holding is the utility firm with the largest financial expenditure, which is growing due to the increased need for debt servicing (Bajo and Primorac, 20I3). A further increase in borrowing costs is expected as the maturity of the Zagreb Holding's bond (20I7) approaches, due to less favourable borrowing conditions and a gradual reduction in the amount of transfers from the city budget, which could also negatively influence the credit rating of the firm.

\section{CoNCLUSION}

The largest part of local government liabilities has been created by utility firms. Therefore, greater attention has to be paid to their financial operations. Closer attention should also be paid to the operations of the City of Zagreb, especially the Zagreb Holding. The City of Zagreb has (together with its Holding) generated more than $60 \%$ of the total cumulative financial liabilities of all local government units. In addition, the government should establish different borrowing constraints for the City of 
Zagreb and for other local government units. Taking into account the existing regulations limiting the total debt of the local sector, the borrowing of the City of Zagreb could easily crowd out borrowing by other local government units.

The financial operations of local government units and their utility firms should be considered simultaneously in order to get a real picture of the financial "health" of the local public sector. Croatian legislation, unfortunately, does not provide for the consolidation of the financial statements of local government units and their utility firms. However, a formal consolidation of their financial statements is very necessary. In addition, it would be beneficial to increase the role of the executive and representative bodies of local government units in the financial planning of the utility firms. A thorough analysis of the impact of the planned borrowing on the financial operations of the utility firm and on the operations of the local unit in which the firm operates should precede each significant borrowing. It is necessary to introduce a system for the credit risk assessment of local government units and their utility firms for a more appropriate allocation of consents for borrowing. Credit risk assessment should be a mainstay for issuing guarantees to local government units and their utility firms.

\section{LITERATURE}

Bajo, A. and Primorac, M., 20I3. Zagreb Holding: Time for restructuring. Newsletter, No. 73.

Bajo, A. and Primorac, M., 20Io. Local government borrowing practice in Croatia. Financial Theory and Practice, 34 (4), 379-406. 